\title{
A Study of Customer Purchasing Behaviour of Automobiles in Kukatpally, Hyderabad
}

\author{
Dr. Mayuri Chaturvedi' ${ }^{1}$ Baddam Harish Reddy² \\ ${ }^{1}$ Lecturer in Management Studies, ${ }^{2}$ Student, Integrated Dual Degree Programme (IDP) \\ JNTUH College of Engineering, Hyderabad, Telangana, India
}

\begin{abstract}
In this competitive world automobiles have become an important part of daily transportation and the competition between different automobile industries lead to the high level innovations in automobiles in order to reach the needs of people. This research attempts to answer some of the questions regarding brand personality of selected cars by conducting the survey. This research will help in knowing what a customer thinks about a given brand of car and what are the possible factors guiding a possible purchase. The main aim of this research is to analyse sales of a particular automobile company and to identify the advertisements and sales promotion activities adopted by the automobile companies. The present study is an attempt to evaluate the consumer purchase behaviour of automobiles. This research highlights the various factors which influence the consumer behaviour towards four wheeler, small sedan cars purchase decision and their behaviour and level of satisfaction.
\end{abstract}

Keywords: Automobiles, Cars, Customer Buying Behaviour

\section{INTRODUCTION}

The Indian Automobile industry includes two-wheelers, cars, trucks, buses and three-wheelers which play very crucial role in growth of Indian economy. The automobile industry in India is world's 4th largest, currently being the world's 4th largest manufacturer of cars and 7 th largest manufacturer of commercial vehicles in 2017. Indian automobile industry has received Foreign Direct Investments (FDI) worth US\$ 18.76 billion between April 2000 and March 2018.According to Gartner the country is expected to top the world in car volumes with approximately quarter billion vehicles on nation's roads by 2050. The Economic progress of this industry is indicated by the amount of goods and services produced which give capacity for transportation and boost the sale of vehicles. There is a vast increase in automobile production with a catalyst effect by indirectly increasing the demand for a number of raw materials like steel, rubber, plastics, paint, glass, electronics and services. Environmental pollution and the need to conserve existing supply of fossil fuels have led to search for alternative fuels. The Government has been moderated and lowered taxes on automobiles, including customs duty. Goods and Services Tax (GST) is also proposed to be introduced across the country from 1 July 2017. Current GST rate on small cars $(<1200 \mathrm{cc})$ and mid size cars (between $1200 \mathrm{cc}$ and $1500 \mathrm{cc}$ ) is $18 \%$ and on luxury cars (1500cc) it is $28 \%$. In India, the automobile industry provides direct employment to nearly 5 lakh persons. There are two different sets of players in the Indian auto industry. Automobile component manufacturers and vehicle manufacturers, which are also referred as Original Equipment Manufacturers (OEMs). While the former set is engaged in manufacturing parts, components, bodies and chassis involved in automobile manufacturing, the latter is engaged in assembling of all those components into an automobile. Our Indian automotive component manufacturing sector consists of 500 firms in the organised sector and in the unorganised sector it consists of around 31,000 enterprises.

\section{Objectives of Study}

The present study based on following objectives:

1. To analyse sales promotion strategies of Maruti Suzuki, Tata and Volkswagen companies.

2. To know the effectiveness of advertisements on customers.

3. To understand the factors that influencing customer to purchase the cars.

4. To know about the purchase decision process.

5. To identify the consumer buying behaviour towards a automobile 4 wheeler small sedan cars.

6. To identify the customer satisfaction.

7. To suggest improve or new sales promotion techniques.

Review of literature:

Bell (1967) He analysed how a customer feels after buying a new car. He also explored the effect of customer's personalities in relation to salesman persuasion that attempts to find customer's post purchase satisfaction. This study was conducted in a large urban area in the western part of United States. Data was collected during the summer months of 1965. During this period, 289 new cars were sold. Attempt was made to interview all but succeeded with 234 persons. Personal interviews were conducted by the investigator from 1-8 days after purchase. It was concluded that person who had high self confidence had very little dissonance i.e. they made their decisions, accepted them and were happy where as persons with low self confidence had low dissonance and they were easily persuaded by salesmen but in between them, the customers with little confidence were highly dissonant and were not easily persuaded. Perhaps their self doubts began to influence their attitude after they completed their purchase. At last it was stated that persuasibility acts as an indirect cause of buyer's dissonance.

Cooper et al. (2001) He intended to inform an understanding of the likely behavioural response to sustainable development policy initiatives in UK. A survey was conducted in the city of Belfast which was a car dependent city. Initiatives included improved domestic energy efficiency, increased densification of housing, 
improved public transport and the introduction of traffic restraint measures such as road user charges. Descriptive statistics had been used to analyse the data. It was concluded that there was significant increase in the rate of decline in the use of public transport. The policy also resulted in the switch from on street to off street car parking.

York (2003) York studied cross national variation in size of passenger car fleets. He further studied multiple factors (demographic, economic and socio political) that potentially influence motorization. Least square regression technique is used to assess the influence of different factors. The sample was collected from 138 nations. The findings suggest that economic development appears to increase motorization and globalization of individualistic social and political structures lead to expansion of car fleets.

R. Ranganathan (2005) His study "Consumer Markets and Buyer Behaviour of Cars", argued that brand image could be increased by the advertisement which clearly showed the features of the cars. The result of the study was that the necessity was the first factor of choosing the car and mileage was an important factor expected from the car.

Satish and Bhardhwaj (2010) they carried out research on information search behaviour among new car buyers. The data was collected from two Indian metros, Bangalore and Chennai. The variables selected for the study were taken from previous research. Firstly the data was analysed with the help of factor analysis and variable so taken were related with attributes of cars. Four factors were extracted styling and comfort, value for money, safety and reliability and miscellaneous etc. the groups had been distinguished using cluster analysis which was applied on search activity variables and personality variables. Four clusters so formed were named as broad moderate searchers, intense heavy searcher, low broad searcher and low searchers. So the study was the first study to segment the car buyers in India and also results were supported with previous studies.

Milind Bade (2011) Milind bade has mentioned that Bajaj Auto Limited is currently trying to move the industry from a commuter to a biker mind set and at present the focus of the company is on keeping the sub brands and the mother brand different and the main motive behind establishing individual brand is to create differentiation which would help Bajaj auto, as an organization to develop relationship easily with its customers.

U. Thiripurasundari (2011) Brand Equity is the added value endowed by the brand to the Product. Although the idea of using a name or a symbol to enhance a product's value has been known to marketers for a long time, brand equity has gained a renewed interest in recent years. The objectives of the study were to analyse the importance of various factors like brand knowledge, brand preference, brand loyalty, brand application etc. in car market in Pondicherry. The primary data were collected from three hundred car owners through an interview schedule. From the five factors, brand application factor has been rated as the most important factor in car industry. This study shows that it is possible to ascertain where a company should focus its improvement efforts in order to make it payoff.

\section{Methodology:}

The study is based on the primary data collected through sample of 60 people who have cars. Questionnaires have been constructed to understand the contribution of various components towards consumer behaviour in automobile industry. The data has been collected through online survey along with demographic details of employees. Secondary data has been gathered from various sources such as books, journals and online resources. The area of this study is consumer purchasing behaviour of automobiles in Kukatpally, Hyderabad. This questionnaire is distributed to 100 people. However, 60 people out of 100 responded by completing the questionnaire. So the final sample size is 60.The questionnaire was sent by email and Whatsapp contacts in the form of google forms. Completed questionnaire were sent back through email and responses were updated in Google forms. Follow-up enquiries were made to enhance timely response by the employees. The data collected was analysed using tables, bar chart and pie chart. Simple arithmetical percentages were used as a measure of proportion of responses. Hyderabad is a place where we can get a lot of different people. Since Hyderabad is technically a developed a lot, these days a lot of Hyderabadians depends on e-commerce, so the respondents residing in Kukatpally, Hyderabad were taken for the study. The Respondents were Students, Employee, Businessman.

\section{Research Hypothesis:}

1. Null hypothesis (HO):- There is no significant relation between current employment status of respondents and price of the automobile.

Alternative hypothesis (H1):- There is a significant relation between current employment status of respondents and price of the automobile.

2. Null hypothesis (H0):- There is no significant relation between age of respondents and features of the automobile.

Alternative hypothesis (H1):- There is a significant relation between age of respondents and feature of the automobile.

\section{DATA ANALYSIS AND INTERPRETATION}

1. GENDER:

\begin{tabular}{|c|c|c|}
\hline Gender & Number of respondents & Percentage \\
\hline Male & 39 & 65 \\
\hline Female & 21 & 35 \\
\hline Total & 60 & 100 \\
\hline
\end{tabular}

Table 1 Gender analysis

2. AGE:

\begin{tabular}{|c|c|c|}
\hline Age & Number of respondents & Percentage \\
\hline Below 20 & 3 & 5 \\
\hline $21-30$ & 19 & 31.7 \\
\hline $31-40$ & 17 & 28.3 \\
\hline $41-50$ & 16 & 26.7 \\
\hline$>50$ & 5 & 8.3 \\
\hline Total & 60 & 100 \\
\hline
\end{tabular}

3. OCCUPATION

Table 2 Age analysis

\begin{tabular}{|c|c|c|}
\hline Occupation & No of respondents & Percentage \\
\hline Business & 16 & 26.7 \\
\hline Employee & 16 & 26.7 \\
\hline Student & 19 & 31.7 \\
\hline Other & 9 & 15 \\
\hline Total & 60 & 100 \\
\hline
\end{tabular}

Table 3 Occupation analysis 
International Journal of Trend in Scientific Research and Development (IJTSRD) @ www.ijtsrd.com eISSN: 2456-6470

4. Rate the following factors that plays an important role while purchasing car?

\begin{tabular}{|l|c|c|c|c|c|c|}
\hline \multicolumn{1}{|c|}{ Factors } & $\begin{array}{c}\text { Most } \\
\text { important }\end{array}$ & $\begin{array}{c}\text { Somewhat } \\
\text { important }\end{array}$ & $\begin{array}{c}\text { Can't } \\
\text { say }\end{array}$ & $\begin{array}{c}\text { Somewhat } \\
\text { not important }\end{array}$ & $\begin{array}{c}\text { Least } \\
\text { important }\end{array}$ & Total \\
\hline Brand & 36 & 21 & 0 & 1 & 2 & 60 \\
\hline Price & 34 & 16 & 1 & 7 & 2 & 60 \\
\hline Advertising & 12 & 25 & 6 & 9 & 3 & 60 \\
\hline Product quality & 50 & 6 & 1 & 3 & 0 & 60 \\
\hline Exterior design & 30 & 24 & 1 & 5 & 0 & 60 \\
\hline Interior design & 35 & 20 & 1 & 4 & 0 & 60 \\
\hline Comfort & 48 & 9 & 3 & 0 & 0 & 60 \\
\hline Safety & 50 & 8 & 1 & 0 & 1 & 60 \\
\hline Fuel efficiency & 45 & 11 & 2 & 2 & 0 & 60 \\
\hline Discounts/promotions & 18 & 22 & 4 & 3 & 13 & 60 \\
\hline
\end{tabular}

Table 4 Factors that plays an important role while purchasing car

5. Are you satisfied with the service department on the following areas?

(H.S: HIGHLY SATISFIED; S: SATISFIED; C.S: CAN'T SAY; D.S: DISSATISFIED; H.D.S: HIGHLY DISSATISFIED)

\begin{tabular}{|l|c|c|c|c|c|c|}
\hline \multicolumn{1}{|c|}{ Areas } & H.S & S & C.S & D.S & H.D.S & Total \\
\hline Satisfied with services & 7 & 47 & 3 & 3 & 0 & 60 \\
\hline Complaint mechanism & 9 & 30 & 13 & 8 & 0 & 60 \\
\hline CRM(customer relationship management) & 7 & 38 & 10 & 4 & 1 & 60 \\
\hline Post sale service & 12 & 26 & 13 & 6 & 3 & 60 \\
\hline Quality of service & 13 & 35 & 5 & 7 & 0 & 60 \\
\hline Pick up and Drop off service & 12 & 30 & 12 & 5 & 1 & 60 \\
\hline Insurance & 9 & 40 & 7 & 1 & 3 & 60 \\
\hline Extra coupons or Discounts & 5 & 28 & 15 & 7 & 5 & 60 \\
\hline
\end{tabular}

Table 5 Consumer satisfaction with the service department

6. When you are looking for new product how do you feel you are influenced by the following advertising techniques?

\begin{tabular}{|l|l|l|l|l|l|l|}
\hline Advertising techniques & Highly effective & Effective & Can't say & Not so effective & Not effective & Total \\
\hline
\end{tabular}

\begin{tabular}{|c|c|c|c|c|c|c|}
\hline TV advertising & 14 & 23 & 14 & 2 & 60 \\
\hline Social media advertising & 6 & 28 & 7 . & 14 & 5 & 60 \\
\hline News paper advertising & 3 & 24 & 12 & 13 & 8 & 60 \\
\hline Celebrity endorsement & 20 & 21 & 3 & 11 & 5 & 60 \\
\hline YouTube videos & 3 & 21 & 10 & 17 & 9 & 60 \\
\hline
\end{tabular}

Table 6 Advertising techniques

Chi-Square analysis

Rate the following factors that plays an important role while purchasing car? [Price]

\begin{tabular}{|l|c|c|c|c|c|c|}
\hline $\begin{array}{c}\text { Current } \\
\text { employment status }\end{array}$ & $\begin{array}{c}\text { Can't } \\
\text { say }\end{array}$ & $\begin{array}{c}\text { Least } \\
\text { important }\end{array}$ & $\begin{array}{c}\text { Most } \\
\text { important }\end{array}$ & $\begin{array}{c}\text { Somewhat } \\
\text { important }\end{array}$ & $\begin{array}{c}\text { Somewhat not } \\
\text { important }\end{array}$ & Total \\
\hline Business & 0 & 1 & 9 & 3 & 3 & 16 \\
\hline Employee & 0 & 0 & 10 & 6 & 1 & 17 \\
\hline Home maker & 1 & 0 & 0 & 3 & 2 & 6 \\
\hline Other & 0 & 0 & 0 & 0 & 0 & 1 \\
\hline Student & 0 & 1 & 14 & 5 & 7 & 60 \\
\hline Total & 1 & 2 & 33 & 17 & & 6 \\
\hline
\end{tabular}

Table 7 Current employment status vs price crosstab count

\begin{tabular}{|c|c|c|c|}
\hline & Value & Df & Asymptotic Significance (2-sided) \\
\hline Pearson Chi-Square & $31.864^{\mathrm{a}}$ & 20 & 0.045 \\
\hline Likelihood Ratio & 29.750 & 20 & 0.074 \\
\hline N of Valid Cases & 60 & & \\
\hline
\end{tabular}

Table 8 Chi-square test

What are the problems that you have encountered with automobile company cars? [Features]

\begin{tabular}{|c|c|c|c|}
\hline Age & No & Yes & Total \\
\hline $21-30$ & 14 & 5 & 19 \\
\hline $31-40$ & 12 & 5 & 17 \\
\hline $41-50$ & 7 & 9 & 16 \\
\hline Less than 20 & 0 & 3 & 3 \\
\hline Total & 33 & 27 & 60 \\
\hline
\end{tabular}

Table 9 Age vs Features crosstab count 
International Journal of Trend in Scientific Research and Development (IJTSRD) @ www.ijtsrd.com eISSN: 2456-6470

\begin{tabular}{|c|c|c|c|}
\hline & Value & Df & Asymptotic Significance(2-sided) \\
\hline Pearson Chi-Square & $15.534^{\mathrm{a}}$ & 4 & 0.004 \\
\hline Likelihood Ratio & 18.738 & 4 & 0.001 \\
\hline N of Valid Cases & 60 & & \\
\hline
\end{tabular}

Table 10 Chi-square test

\section{Major findings of the study are:}

1. It is observed that $31.7 \%$ of the respondents who purchase automobile are 21-30 age group.

2. The study reveals that out of total respondents, $65 \%$ are males and $35 \%$ are females. It is observed that male occupied they role in the study sample.

3. It is observed that $31.7 \%$ of respondents are students, $26.7 \%$ of the respondents are businessman, $26.7 \%$ of the respondents are employee.

4. It is observed that $78.3 \%$ of the respondents own one car.

5. It is observed that $21.7 \%$ of the respondents own Maruti Suzuki, $20 \%$ of the respondents own Tata, $16.7 \%$ of the respondents own Ford.

6. It is observed that $55 \%$ of the respondents say brand is important, $50 \%$ of the respondents say price is important, $37 \%$ of the respondents say advertising is important, $55 \%$ of the respondents say product quality is important, $50 \%$ of the respondents say exterior design is important, $55 \%$ of the respondents say interior design is important, $54 \%$ of the respondents say safety is important, $56 \%$ of respondents say fuel efficiency is important and $40 \%$ of the respondents say discounts or promotions are important. Respondents say safety, fuel efficiency, comfort and quality are most important and advertising, discounts and price doesn't play much important role.

7. It is observed that $80 \%$ of the respondents are satisfied with services, $40 \%$ of the respondents are satisfied with complaint mechanism, $48 \%$ of the respondents satisfied with CRM, $48 \%$ of respondents satisfied with post sale service and quality of service, $42 \%$ of respondents satisfied with pick up and drop off service, $49 \%$ of respondents satisfied with insurance, $35 \%$ of respondents satisfied with coupons and discounts.

8. It is observed that $61.6 \%$ of respondents influenced by TV advertising, $56.6 \%$ of the respondents influenced by social media, $45 \%$ of the respondents influenced by newspaper, $68.33 \%$ of the respondents influenced by celebrity endorsement, $40 \%$ of the respondents influenced by youtube videos.

9. It is observed that $70 \%$ of the respondents prefer to buy next from the same company.

10. It is observed that $51.6 \%$ of the respondents faced problem with fuel efficiency and $65 \%$ of the respondents are ok with maintenance problem of automobile company cars.

11. Fuel efficiency and features has to be improved in order to satisfy customer.

12. There is a significance relation between occupation of the respondent and price of the automobile.

13. There is a significant relation between age of the respondent and feature problems encountered with automobile company.

14. There is a significant relation between gender and discount and promotions of automobile company.

15. There is a significant relation between occupation and satisfied with services of automobile company.

\section{Limitations of the study}

1. The study is restricted to Hyderabad.

2. Sample size is limited to 60 .

3. Some of the respondents may not give accurate information, as they may not like to reveal their actual identity.

\section{SUGGESTIONS}

To ensure that the product finds a place in the minds of consumers, the manufactures should position their products through sales promotional activities such as advertisement through an effective media. Indian consumers are strongly influenced by sports personalities, film stars and celebrities. For positioning the consumer durables like cars, the manufacturers can utilize the endorsement of these celebrities. The respondents perceive that driving comfort and fuel economy are the most important features of passenger car followed by availability of spare parts and price of the car. Thus the manufacturers should design the product giving maximum weightage to these factors and produce fuel economy with comfort cars. Due to steady increase of petrol/diesel prices, fuel efficiency needs to be improved. Constant improvement and technical upgradation for better fuel efficiency alone with attract more customers. Availability of service station atleast every $25 \mathrm{kms}$ on National highways. Experienced foremen are needed at all service stations. All service stations should be equipped with spare parts at reasonable cost. Free service can be extended to five years. For hot countries like India, it is recommended to fix Sun Roof Glass on the top of the car. But it should be provided as Original Equipment at a reasonable rate.

\section{CONCLUSION}

Consumer Behaviour consist of all human behaviour which reflects in making purchase decisions. An understanding of the consumer behaviour enables a marketer to take marketing decisions which are compatible with its consumer needs. There are four major classes of consumer behaviour determinants and expectations, namely, cultural, socioeconomic, personal and psychological. The socio-economic determinants of consumer behaviour consist of age, martial status, occupation, education, income, family size etc. The present study is an attempt to evaluate the consumer purchase behaviour of four wheeler small sedan cars. This study highlights the various factors which influence the consumer behaviour towards four wheeler purchase decision and their behaviour and level of satisfaction. In this study most of the respondents are students. This findings of the study will help to analyse the sales promotion strategies of automobile company and effectiveness of advertisements on customers. According to this study most of the respondents influenced by celebrity endorsement and TV advertising. So celebrity endorsement and TV advertisement will effect on consumer purchasing behaviour. According to this survey Maruti Suzuki, Tata, Ford are popular brands in Kukatpally, Hyderabad. Customers are satisfied with services provided by the companies. Customers facing problems with fuel efficiency. So in order to satisfy customers fuel efficiency has to be improved. 


\section{REFERENCES}

[1] Cooper et al, A.; Berry, Leonard L.; Zeithaml, Valarie A., -Understanding customer expectations of service, Sloan Management Review; Spring 2001; 32, 3; ABI/INFORM Global, p. 39.

[2] Gerald D. Bell, -Self-confidence and Persuasibility among Car Buyers\|, Journal of Marketing Research, 1967, pp. 46-52.

[3] http://shodhganga.inflibnet.ac.in

[4] http://www.ijsrp.org

[5] http://www.indianmirror.com/indianindustries/automobile.html

[6] http://www.shanlaxjournals.in

[7] https://en.wikipedia.org/wiki/Automotive_industry_in_ India

[8] https://www.ibef.org/industry/automobiles

[9] https://www.mbaknol.com/marketingmanagement/the-engel-kollat-blackwell-model-ofconsumer-behavior/

[10] https://www.researchgate.net
[11] https://www.researchgate.net/publication/50916601_ Stimulus-Response_Model

[12] https://www.scribd.com

[13] Milind Bade, - Local brand vs. Global brand syndrome-A study with reference to Indian car industry, Advances in Management, Vol. 3, No. 10, 2011, pp. 55-59.

[14] Newman, -Although US cars are improving, imports still win quality survey, Wall Street Journal, 1972, p.31.

[15] Ranganathan. R, -Consumer markets and Buyer Behaviour of Cars, Indian Journal of Marketing, April 2005, pp. 27-34.

[16] Sathish and Bhardhwaj, -Passenger Car Industry in India, Indian Journal of Marketing, Volume XXXVIII, Number 11, November 2010, pp.22-26.

[17] The Indian Automobile Industry, Statistical Profile, SIAM, 2007-08.

[18] U. Thiripurasundari, -Factors Facilitating Brand Equity Dynamics - A Study on Indian Car Industry, International Refereed Research Journal, www.researchersworld.com, Vol. - II, Issue -2, April 2011, pp.27-32.

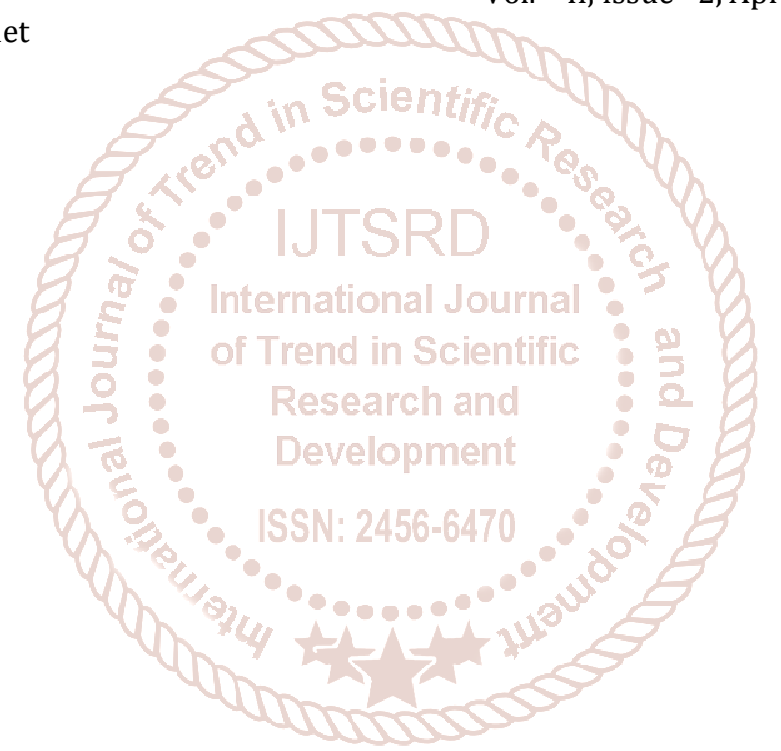

